\title{
Chapter 3 \\ The Second and Third Generation in Rotterdam: Increasing Diversity Within Diversity
}

\author{
Maurice Crul, Frans Lelie, and Elif Keskiner
}

\subsection{Introduction}

According to the city's statistics, Rotterdam passed the threshold of becoming a majority-minority city in 2015, meaning that the people of Dutch descent now are a numerical minority. In the Netherlands the official definition of a person of Dutch descent is someone born in the Netherlands whose both parents are also born in the Netherlands. The estimation is that in 2030 in Rotterdam people of Dutch descent will only represent $40 \%$ of the city's population (Gemeente Rotterdam 2012). This $40 \%$ is obviously not an ethnically homogeneous group, since it also includes people whose grandparents migrated to the Netherlands, the third generation.

A recent publication of the city council (Gemeente Rotterdam 2018) clearly depicts the fluidity of Rotterdam's population. People born in Rotterdam whose parents are also Rotterdam natives only make up $9 \%$ of the population. A quarter of the population (23\%) is born in Rotterdam while their parents were not, and by far the largest share of this $23 \%$ has parents or grandparents who came as migrants. The remaining part - the vast majority of Rotterdam's population - are people who are not born in Rotterdam. They either moved there from another city in the Netherlands or came from another country.

The previous chapter of this book concluded describing postwar labour migration to the harbor city. This included people from Spain, Italy, Turkey, Morocco and the Cape Verdean Islands. The migrant groups presently representing the largest ethnic minority groups in Rotterdam are, in order of numbers, people of Surinamese, Turkish, Moroccan, Antillean and Cape Verdean origin. Rotterdam's Cape Verdean community is the largest in the world outside the Cape Verdean Islands. These groups mostly migrated between the 1960s and the 1980s. The people from Surinam and the Antilles migrated as a result of the decolonization process around that time.

M. Crul ( $\bowtie) \cdot$ F. Lelie $\cdot$ E. Keskiner

Free University Amsterdam, Amsterdam, The Netherlands

e-mail:m.r.j.crul@vu.nl; f.lelie@vu.nl; e.keskiner@vu.nl 
Table 3.1 Five largest migrant groups in Rotterdam, according to generation, in absolute numbers

\begin{tabular}{l|l|l|l|l}
\hline & 1st generation & 2nd generation & 3rd generation & Total \\
\hline Surinamese descent & 28.435 & 24.106 & 5.012 & 52.541 \\
\hline Turkish descent & 22.218 & 25.535 & 2.535 & 47.748 \\
\hline Moroccan descent & 18.844 & 24.704 & 1.562 & 43.548 \\
\hline Antillean descent & 15.005 & 9.445 & 1.289 & 24.450 \\
\hline Cape Verdean descent & 8.625 & 6.826 & 1.313 & 15.451
\end{tabular}

Source: OBI, Gemeente Rotterdam (2017)

In the wake of independence, many Surinamese and Antillean people decided to opt for the Netherlands while this was still possible (Table 3.1).

Over the past decades, new migrant groups started coming to Rotterdam. The share of European migrants among the total number of people migrating to the city is rising most sharply. In total they now make up $8 \%$ of the population, similar to the size of the long-established group of Surinamese descent. A first new wave of European migrants came after the collapse of the Soviet Union in 1991. More recent extensions of the EU to the East actually gave a further push to make Rotterdam a majority-minority city. Newly arrived people from Poland form the fastest growing group in Rotterdam (Boom et al. 2014, 5), but still only account for $1.1 \%$ of the population (idem, 4). Over the last decades, people also increasingly come from countries further away from Europe: especially Sub-Saharan Africa and the Middle East. Also, there is an increasing number of people that came as refugees, for instance from Iraq and Somalia (Boom et al. 2014, 4). More recent, due to the financial crisis, there is migration from South European countries like Spain and Italy. These migrants are usually still young and most of them do not yet have families.

The most unsteadfast group in the city is formed by the people of Dutch descent. They move to the city for study and work in large numbers but leave the city in equal numbers too. In the year 2013 alone, about 12,000 people of Dutch descent left Rotterdam, while an equal number entered the city. This means that the whole population of Dutch descent has a turnover rate of slightly more than 10 years (Boom et al. 2014, 8). Of course, a part of these people of Dutch descent is steadfast in Rotterdam, but there are also many people in this group who only stay in Rotterdam for a shorter period. In contrast, the children of the five migrant groups that came in the 1960s and 1970s as labour-migrants and the children from the former colonies form the most established and stable groups in the city. Children and grandchildren of first generation migrants are very loyal inhabitants. They usually stay for their studies and also choose Rotterdam as the place to start their own family. They are strongly rooted in Rotterdam because most of their close family lives there too. Rotterdam neighborhoods like Delftshaven, Charlois or Feyenoord are the neighborhoods where these groups now already live for three generations.

Children or grandchildren of the five largest migrant groups today make up more than a third (already 40\% in 2010) of all children under age 15 in Rotterdam (Entzinger and Scheffer 2012). They are equal in number to the youth of Dutch descent (39\% of children under age 15 in 2010). Together with children of other 
non-western migrants, the children of the five largest migrant groups form the majority of children in Rotterdam (53\% under age 15 in 2010).

In this chapter we will look at how the position of the second and third generation of these five largest post war migrant groups has evolved in relation to the first generation. We will pay a bit more attention to the two most disadvantaged groups, people of Turkish and Moroccan descent. They exemplify why we believe that a 'superdiversity lens' is needed to clarify the developments in the city. One of the main premises of superdiversity is that, next to looking at ethnicity, we need to look at other, equally important, groupings. For instance, based on the education level, labour market position or income position of people in the city. In this chapter we will show that the diversity within the group of Turkish and Moroccan descent is increasing over generations, leading to strong within-group differences in the socio- economic position of the second and third generation. This fundamentally questions whether it is still academically useful to analyze all kinds of social and economic phenomena in the city through the ethnic lens, or if a 'superdiversity lens' is more appropriate.

\subsection{The Pioneering First Generation}

The official figures published to depict the socio-economic situation in Rotterdam for migrants of the first generation always include both people who came as the pioneering generation, those who came as the first of their group, as well as those who came more recently to Rotterdam, new migrants from that same country of origin. There are no figures available from the city's statistical bureau that show the pioneering first generation separately. Therefore, one should keep in mind that the figures we present in Table 3.2 below include both the pioneers who might live in Rotterdam since decades as well as a first generation of recent migrants. However, these official figures give an indication of the differences between the various first generation groups. Table 3.2 shows the educational level divided up in three categories: low, middle and high. Low here means primary school or less and the lowest levels of vocational education. Middle represents senior vocational education or an upper secondary diploma. High represents a higher education diploma.

Overall the figures show that the first generation is low educated. The majority only finished education at the lowest levels. The Moroccan and Turkish first generation acquired their schooling mostly in their country of origin. The older Surinamese and Antillean first generation mostly attended a Dutch curriculum due

Table 3.2 Educational level of the first generation, according to ethnic groups in Rotterdam

\begin{tabular}{l|l|l|l}
\hline & Low (\%) & Middle (\%) & High (\%) \\
\hline Surinamese descent & 44 & 43 & 13 \\
\hline Turkish descent & 66 & 29 & 6 \\
\hline Moroccan descent & 69 & 23 & 8 \\
\hline Antillean descent & 52 & 38 & 10 \\
\hline
\end{tabular}

Source: Gemeente Rotterdam (2017) 
Table 3.3 Education of the parents of the second generation Turkish and Moroccan respondents, TIES Survey in Rotterdam

\begin{tabular}{l|l|l|l|l}
\hline & $\begin{array}{l}\text { No schooling or } \\
\text { Quran school (\%) }\end{array}$ & $\begin{array}{l}\text { Primary } \\
\text { school (\%) }\end{array}$ & $\begin{array}{l}\text { Secondary } \\
\text { education (\%) }\end{array}$ & $\begin{array}{l}\text { Post-secondary and } \\
\text { higher education (\%) }\end{array}$ \\
\hline $\begin{array}{l}\text { Turkish 1st } \\
\text { generation fathers }\end{array}$ & 9 & 43 & 39 & 9 \\
\hline $\begin{array}{l}\text { Turkish 1st } \\
\text { generation mothers }\end{array}$ & 42 & 28 & 28 & 2 \\
\hline $\begin{array}{l}\text { Moroccan 1st } \\
\text { generation fathers }\end{array}$ & 18 & 51 & 25 & 5 \\
\hline $\begin{array}{l}\text { Moroccan 1st } \\
\text { generation mothers }\end{array}$ & 46 & 32 & 20 & 2 \\
\hline
\end{tabular}

Source: TIES Survey 2008

to the colonial relationship at that time. The figures clearly show that the first generation of Moroccan and Turkish descent is the lowest educated, while first generation Surinamese migrants are relatively the highest educated. The oldest cohort of the Turkish and Moroccan first generation came to the Netherlands in the 1960s and 1970s to work in shipyards and factories. They were followed by their wives and young children about 8-10 years later. The oldest cohort of the first generation of Antillean and Surinamese descent largely came in the 1970s and 1980s. They were much better educated than the early Moroccans and Turks. The very first Surinamese and Antillean migrants were actually often students coming to the Netherlands to enroll in higher education unavailable in their home countries.

For this chapter we will also frequently use data from the 2008 TIES survey for Rotterdam. ${ }^{1}$ We use the TIES survey, even though it is 10 years old, because it is the only survey where the first and the second generation in Rotterdam can be linked to each other at the city level (Crul et al. 2012). The TIES survey sampled second generation Turkish and Moroccan respondents representatively according to their numbers in neighborhoods in Rotterdam. Through the respondents detailed information about their parents was also obtained. This makes the TIES survey the only large-scale survey in Rotterdam providing detailed information of the pioneering first generation separately and enabling an assessment of the intergenerational mobility from the first to the second generation. The TIES survey reveals that the majority of the fathers and mothers of the first generation were even lower educated than Table 3.2 suggests. They only attended primary school or did not go to school at all, which is true especially for many of the mothers. The somewhat better outcomes in Table 3.2 are the result of the new first generation, who often come as a marriage partner for a second generation spouse and who usually are much better educated than the pioneering first generation who came in the 1960s and 1970s (Table 3.3).

\footnotetext{
1 'The Integration of the European Second generation' (TIES). The TIES survey was conducted in 15 cities in 8 countries and involved almost 10,000 respondents between the ages of 18 and 35 . In each city, 250 respondents from each target group were interviewed. In the Netherlands, the interviews were conducted in Amsterdam and Rotterdam.
} 


\subsection{The Second Generation Inherits the City}

The second generation of Surinamese, Turkish and Moroccans descent are almost equal in size and are the largest ethnic groups in Rotterdam (see Table 3.1). Only between $5 \%$ and $10 \%$ of the youngsters under age 23 of Surinamese, Turkish and Moroccans descent belongs to the first generation (Boom et al. 2014, 11). This is different for youngsters under age 23 of Antillean descent: about a third of them belong to the first generation (Idem, 11). The youngsters of Cape Verdean descent form the fifth largest youth group in Rotterdam, close in number to the Antillean youth group.

Children of immigrants from Eastern European countries are now also a fastgrowing group, with children from Polish and Bulgarian descent being the most numerous (Engbersen 2014, 7). About half of these children of Polish descent and only a third of the children of Bulgarian descent are born in the Netherlands and belong to the second generation (Boom et al. 11).

As mentioned in the introduction, the largest group of people born in Rotterdam are children of immigrants. Quoting Phil Kasinitz and his colleagues (2008) on the same trend in New York City, we can say that these children of the second generations will inherit their neighborhoods and, to a certain extent, the city of Rotterdam.

The increased diversification of ethnic groups in the city is reflected most clearly in elementary and secondary schools. Class rooms with pupils of 15 or more different ethnic origins have become more rule than exception. The differentiation in generations has also become more pronounced. Third generation Turkish-Dutch pupils now grow up side by side with first generation Polish pupils. This simultaneity, as Arnaut names it, is also an important characteristic for the superdiverse reality in today's big cities (Arnaut 2012).

\subsection{Diversity Within Ethnic Groups}

Next to a growing diversity of ethnic groups in the city we see an increased diversity within ethnic groups. This diversity is becoming most visible in the second generation and will be even more visible in the third. The general idea of assimilation theories is that ethnic groups as a whole follow a possible upward or downward pathway (Portes and Rumbaut 2001). The emphasis is usually on ethnic and socio-economic characteristics of the first generation that influence the type and/or speed of these pathways. Compared to the first generation Moroccan and Turkish migrants, the Surinamese and Antillean first generation was much more socio-economically diverse to start with (Van Niekerk 2007). Both lower educated as well as higher educated Surinamese and Antilleans migrated to Rotterdam. Within the first generation Antillean group, also many (42\%) have a partner from another ethnic origin, 
mostly Dutch (Entzinger and Scheffer 2012, 121). The children of mixed marriages belong, according to the official definition used by Dutch statistical bureaus, to the Antillean ethnic group, thus actually adding to the diversity in the second generation. The blurring of ethnic boundaries through mixed marriages is an important new phenomenon not yet properly dealt with in statistics. School- and labour market outcomes for the second generation Antilleans indeed show polarized outcomes reflecting the already existing differences in the first generation, but even more pronounced. A considerable group is able to reach a middle-class position, but an equally large group seems to be in a rather precarious position. Young males of Antillean descent are overrepresented in crime statistics, while young females are overrepresented in the group of teenage single mothers. Of the male youngsters, $11 \%$ is registered as being suspected of a crime (idem, 50) and 14\% of the AntilleanDutch women between 15 and 20 already has a child (mostly being a single mother) (Boom et al. 2010, 15). About half of the Antillean-Dutch households with children are single mother households in Rotterdam (idem, 65). The polarization within the Antillean-Dutch group is maybe best visible in secondary education. Almost a quarter $(24 \%)$ of the pupils of Antillean descent are enrolled in a form of special education, the lowest tracks, (bijzonder onderwijs or praktijk onderwijs), which is five times more than pupils of Dutch descent (Boom et al., 2). The poor results of these Antillean-Dutch pupils can be partly explained by the large share that entered the Dutch school system at a later age due to recent migration. At the same time, an equally large group (27\%) is found on the highest, pre-academic tracks (Havo/Vwo).

The second generation Surinamese are counted as one ethnic group but are ethnically very diverse. The largest ethnic group within the Surinamese group in Rotterdam are children whose great-grandparents originally came from the Indian subcontinent. The second largest group are the descendants from people brought to Surinam as slaves from West Africa. Much smaller groups have Chinese roots or have their roots in Java in Indonesia (Oudhof et al. 2011, 101). The statistical data about the Surinamese second generation in Rotterdam are scarce, partly because there are less problems in this group compared to the Antillean second generation. In the Surinamese second and third generation the balance is more tilted towards the successful group. For instance, more than a third of the Surinamese-Dutch pupils are enrolled in the highest tracks of secondary education while only $10 \%$ are found in the two special education tracks (Boom et al. 2014, 22). They still do show an overrepresentation in the category of people with low levels of education compared to their peers of Dutch descent (30\% versus $17 \%$ ), but the gap (13\%) is much smaller than that with the Antillean-Dutch pupils (gap of 33\%) or the Turkish-Dutch pupils (gap of 22\%). Looking at the size of the Surinamese-Dutch population in Rotterdam, the actual share of students in Higher Education (Hbo and University) of Surinamese descent is equally big as that of Rotterdam youngsters of Dutch descent. Many Surinamese-Dutch students are following the middle level track in high school and then continue onto middle vocational education and then move onto 
Table 3.4 Educational level of the second generation Turkish and Moroccan respondents, TIES Survey in Rotterdam

\begin{tabular}{l|l|l|l}
\hline & $\begin{array}{l}\text { Early school leaver } \\
(\%)\end{array}$ & $\begin{array}{l}\text { Middle level education } \\
(\%)\end{array}$ & $\begin{array}{l}\text { Higher education } \\
(\%)\end{array}$ \\
\hline Turkish 2nd generation & 29 & 44 & 27 \\
\hline $\begin{array}{l}\text { Moroccan 2nd } \\
\text { generation }\end{array}$ & 19 & 54 & 27 \\
\hline
\end{tabular}

Source: TIES Survey 2008

higher vocational education to earn a bachelor degree. On many indicators concerning choices in life the Surinamese second generation makes similar choices as their peers of Dutch descent, like for instance the age of having their first child or the choice to move out of the city to satellite towns. But, also in terms of identifying as Dutch: the Surinamese second generation does that to almost the same extent as their peers of Dutch descent (Scheffer and Entzinger 2012).

The story of both the Turkish and the Moroccan second generation is very different from that of the Surinamese or Antillean second generation. Here, the main trend is upward social mobility compared to their parents because their parents where overall very low educated. For the children of these two groups of labour migrants we will use the outcomes of the TIES survey in Rotterdam, which allows us a much more detailed picture of the second generation than the limited administrative data we have for the second generation Surinamese and Antilleans.

According to segmented assimilation theory the low socio-economic position of the parents predicts a downward trajectory in the second generation, with only modest social mobility for the majority of the group and a substantial group that is at risk. However, the actual situation in the second generation is different: a considerable group has attained higher education (See Table 3.2). The group of early school leavers is, however, also considerable. If anything, the second generation is characterized by a strong polarization in their school outcomes (Table 3.4).

The TIES survey allows us to analyse intergenerational social mobility patterns. In the case of the Moroccan parents we find no significant effects of differences in educational levels of the parents on the education of their children. However, we have to keep in mind that the first generation Moroccan parents were indeed, overall, very low educated which leaves little room for variation. For the Turkish group we do find significant differences in the outcomes, both in relation to the education of the mother $\left(\mathrm{P}^{* * *}<0.01\right)$, as well as of the father $\left(\mathrm{P}^{* * *}<0.01\right)$. The variation in the education of the Turkish first generation is larger. The older cohort of first generation Turkish fathers and mothers more often did not go to school, while the younger first generation Turks more often went to primary school and followed some years of secondary school. Keskiner (2015) argues that social class differences among first generation Turkish migrant parents have emerged over time. She shows how first generation Turkish migrant parents that arrived in the Netherlands as adoles- 
cents and received some years of training, became more encouraging for their children's education. So, over time the parental education of the first generation became more varied and, mostly, improved, and, as a result, the support parents could give has changed. In the Moroccan first generation we do not see such a clear improvement in educational level of the first generation parents, but we do see a different mentality developing towards education over time. First generation parents become more involved in the school affairs of their children. Our data suggest that the younger cohort of the second generation (between 18 and 25) receives much more educational support of the parents compared to the older cohort (26-35). They get considerably more help with homework, parents more often control time spent on homework, more often talk about the importance of school and more often meet with the teacher.

Not only the first generation parents have changed in their attitudes and practices over time, but also the structural conditions have changed. Pre-school facilities had for instance improved. In the younger cohort of the Turkish second generation we see a significant increase $\left(\mathrm{P}^{* * *}<0.01\right)$ in pre-school attendance. In the group of Moroccan descent, we do not find a significant effect for the younger age cohort. Also, schools have started to become better prepared for teaching children of immigrants: Second language classes were introduced and extra funding was provided to schools with large proportions of immigrant children. This money was mostly used to bring down the class size (Crul 2001). As a result of all these measures together we see twice as many children entering secondary school at the highest level (Vwo) in the younger age cohorts of the second generation. The individual changes together with the structural changes result in a significant increase of respondents in higher education among the younger age cohort: a 15\% increase in the younger cohort of the Turkish second generation and an $11 \%$ increase in the Moroccan younger cohort (18-25) compared to the older cohorts of the second generation between 25 and 35 . Pertaining to a different age cohort thus impacts the diversity within the second generation.

The TIES survey also allows us to see what happens next for the two second generation groups that end up at the opposite end of the educational ladder. The TIES survey shows that the large differences in educational attainment within the second generation on their turn propel a further dynamic through the partner choice. Young second generation adults that have acquired a higher education diploma more often marry a high educated partner while early school leavers more often marry low educated partners. These partner choices result in big differences between the employment situations of both partners and, as a consequence, the income situation in their households. Changing gender roles play an important role here. Among the higher educated respondents, gender roles change dramatically compared to their parents, while the low educated second generation mostly reproduces the traditional gender roles of their parents (see also Crul et al. 2013). Those in possession of a higher education diploma either marry someone who is also higher educated (38\% 
for the Turkish second generation and $27 \%$ for the Moroccan second generation) or has middle-level educational qualifications (29\% and $47 \%$ respectively). In the majority of these couples both partners enter the labour market, resulting in a double income. This allows them to buy an apartment or rent in the private sector. They have the opportunity to leave the working-class neighborhood of their parents. Their children will go to schools in a middle-class neighborhood and at home they will have the resources of well-educated families (Crul et al. 2013).

The story of the upwardly mobile group resembles what is often understood as the classical form of assimilation over time. Nevertheless, we also see a second trend that is certainly at odds with classical assimilation: The early school leavers move into the opposite direction. They often $(60 \%$ in the case of the Turkish second generation and $32 \%$ in the case of the Moroccan second generation) marry someone who is also an early school leaver. The men occupy, at best, the same position as their fathers, but the risk of being unemployed is nowadays actually much bigger for them. Their female marriage partner, frequently newly arriving from Turkey or Morocco, is often not working but taking care of the children full time. This means that in these households there is, at best, only one income and generally this income is not very substantial. Many second generation women who are early school leavers reproduce the position of their mother. In the case of female early school leavers from Turkish descent less than half $(48 \%)$ is active on the labour market, while this is true for about two third (63\%) of the Moroccan female early school leavers. They often marry someone from their parents' birth country (76\% of the partners are born in Turkey and $68 \%$ are born in Morocco) and many of them are low educated. The chances for that person to get a job are bleak. In the couples in the Turkish group about a quarter of the male partners $(27 \%)$ who were born in Turkey has no paid job and of the partners born in Moroccan it is more than a third (38\%). The places where they can afford to live are limited to social housing areas in the most deprived neighborhoods. Their children will go to the worst performing schools of the city. The opportunities for third generation children in this group actually look worse than for the second generation.

In traditional assimilation theories, differences in social mobility patterns are explained through differences in group averages between different ethnic groups and/or the majority group. Assimilation theories put a big emphasis on ethnic and socio-economic background characteristics of the first generation. We indeed found important effects for the background characteristics of the first generation. But we also found that a substantial part of the within-group differences in the second and third generation is the result of an accumulation of outcomes that are the direct result of choices that the high educated second generation made differently than their less successful peers. For instance, marrying a high educated partner and the choice of women to participate in the labour market. These choices, strongly motivated by educational success, form an often-overlooked part in the explanation of within-group differences. 
In the next two paragraphs we will see how this increased socio-economic diversity within the second generation affects other integration indicators, like their outlook on gender equality, sexuality or their religious practices. We can only do this for the Turkish and Moroccan second generation based on the available TIES data in Rotterdam; for their Surinam-Dutch and Antillean-Dutch peers, we have no comparable data.

\subsection{Polarization in the Turkish and Moroccan Second Generation: Progressive Views on Gender Equality and Sexuality Versus New Forms of Conservative and Religious Orthodoxies}

In the previous paragraph we described the subgroup of Turkish-Dutch and Moroccan-Dutch early school leavers that marry early, mostly with someone from the country of migration of their parents. We will now look more in-depth at what sort of attitudes and opinions early school leavers in the Turkish and Moroccan second generation hold towards topics like sexuality, religion and social relations. In the group of early school leavers of Turkish descent, the general trend is that of withdrawal in their own ethnic group and a tendency towards conservative and orthodox religious opinions. The Moroccan-Dutch early school leavers show an opposite reaction. This group mixes a lot with people from other ethnic backgrounds than their own, generally has progressive views on sexuality and is the most unreligious group in the Moroccan community.

In the group of Turkish-Dutch early school leavers, the majority (54\%) only has friends of Turkish descent among their three best friends; of their Moroccan-Dutch peers only $17 \%$ reports that their three best friends are of Moroccan descent. A quarter $(26 \%)$ of the Moroccan-Dutch early school leavers says they do not have a religion, which is a three times higher percentage than for the Moroccan-Dutch group as a whole. In the Turkish-Dutch group of early school leavers it is also high $(15 \%)$, but the difference with the whole group (10\%) is much smaller. The religious Turkish-Dutch respondents, on the other hand, are also far more orthodox. Among Turkish-Dutch early school leavers, a third of the respondents (33\%) states that religion should be represented in politics and society, while this is only true for $22 \%$ of the Moroccan-Dutch early school leavers. To the more extreme question whether religion should be "the ultimate political authority" is answered affirmatively by $22 \%$ of the Turkish-Dutch early school leavers, but only by $7 \%$ of their Moroccan-Dutch peers. A similar difference we find for questions on virginity before marriage. In the Turkish-Dutch group the majority answered that sex before marriage is never allowed, while this is only true for a third of their MoroccanDutch peers. 
These big differences between early school leavers of Turkish descent and of Moroccan descent seems to be a specific Rotterdam phenomenon. In the TIES survey in Amsterdam these two groups show much more similar outcomes. One big difference between Rotterdam and Amsterdam seems to be that the second generation Moroccans in Rotterdam more often have lower educated friends of Dutch descent. One could say that they assimilate into the 'white' Rotterdam underclass. The fact that the lower-class population of Dutch descent in Rotterdam is significantly bigger than in Amsterdam makes this also more likely. According to the segmented assimilation theory (Portes and Rumbaut 2001), assimilating into the underclass results in marginalization and internalization of norms that deviate from the mainstream. The outcomes for the Moroccan-Dutch early school leavers, however, go against this: their secularization actually seems to go faster and they hold opinions, for instance about sexuality, that are in line with mainstream opinions in Dutch society (Crul 2015).

The proximity of lower-class 'white' Dutch people apparently triggers a different reaction among Turkish second generation early school leavers. They withdraw into their own ethnic group. This type of segmented assimilation, according to Portes and Rumbaut (2001), should lead to upward social mobility and a positive identification with both their own community and Dutch society. In this group, however, marginalization and adherence to orthodox norms that are at odds with mainstream notions on the separation of state and religion seem to be the stronger tendency.

In Rotterdam, the group of high educated second generation Turks and Moroccans is slightly bigger than the group of early school leavers. These successful young people play a key role in the future scenario of their communities. Especially high educated second generation women are fundamental for the emancipation of the group as a whole. For example, the vast majority of them rejects the statement that "women with young children should not work outside the home". Only 6\% of the high educated Moroccan-Dutch women do agree to this statement, as do $15 \%$ of high educated Turkish-Dutch women. In comparison, $10 \%$ of the high educated women of Dutch descent agree to this statement. It is not surprising that high educated women are the greatest advocates of the idea that mothers of young children should also be able to work. After years of study, they want to cash in their efforts made. And indeed, in our Rotterdam sample we found that all the high educated women with a partner are active on the labour market. The common Dutch 'polder compromise' in the highly educated second generation families with young children is that the women work 3 or 4 days a week, just like their peers of native descent. The biggest rupture this high educated group is making with traditions of their ethnic community concerns the topic of family honor and virginity. Virginity before marriage is still considered to be the norm by low educated members of the Turkish second generation, but their high educated peers more openly demand the right to make decisions about their own sexuality. A large majority (61\% of the TurkishDutch and $66 \%$ of the Moroccan-Dutch respondents) says that they find it acceptable 
to have sex before marriage, either "in any circumstances", or "subject to certain conditions". These young people all grew up in families of low educated labour migrants. With this statement they are quite strongly distancing themselves from the predominant traditional opinions about sexuality of their ethnic communities.

But among the high educated we also find considerable differences between the Turkish-Dutch and the Moroccan-Dutch group. In this case it is the Turkish-Dutch who more often state that they do not have a religion (12\%), compared to only $5 \%$ of the Moroccan-Dutch high educated. Among the high educated Moroccan-Dutch group, $65 \%$ prays daily or even five times a day, while this only true for $16 \%$ in the high educated Turkish-Dutch group. When it comes to adhering to more orthodox religious statements, the high educated Moroccan-Dutch also more often do so. Of the high educated Turkish-Dutch respondents, $12 \%$ agrees to the statement that religion should be represented in politics and society, while 28\% of the MoroccanDutch group does. The high educated Moroccan-Dutch respondents also more often have three best friends who are co-ethnics (21\%) than the Moroccan-Dutch early school leavers (17\%). In Amsterdam, we do not find the same trends among the high educated Moroccan second generation. The big difference between Rotterdam and Amsterdam is that in Rotterdam the high educated Moroccan second generation reports significantly $\left(\mathrm{P}^{* * *}<0.01\right)$ more experiences of discrimination than their Amsterdam peers, even though in Amsterdam a bigger share of the high educated Moroccan second generation women wear headscarves, which is usually highly correlated with discrimination experiences. The political climate and the huge support for anti-immigrant party Leefbaar Rotterdam that especially targets people of Moroccan descent - about one in three voters of Dutch descent supports this party - are likely to be an important factor for the reactive identity we find among high educated Moroccan-Dutch respondents in Rotterdam.

\subsection{Future Scenario's}

The older cohort of the second generation of the four largest migrant groups who came to Rotterdam between the 1960s and 1980s are now adults and they are starting their own families. The socio-economic position of the so-called second generation is considered the litmus test whether or not the integration of migrants has been successful. On average the outcomes for the second generation still lag far behind those for the children of Dutch descent. The fact that in Rotterdam the population of Dutch descent is lower educated than, for instance, in Amsterdam makes closing the gap in Rotterdam somewhat easier (See also Entzinger in Chap. 9 of this volume). Average outcomes for the second generation leave an important trend unseen: polarization. A considerable group, between a quarter and a third, among the second generation is doing extremely well, especially taking the low starting position of most of their parents into account. Second generation Surinamese, Antillean, Moroccan and Turkish professionals are now young professionals working in position as teachers, dentists, lawyers, local policy makers or accomplished 
businessmen in Rotterdam society. These young professionals often marry someone who is equally high educated and successful. In these households both partners work and their double income enables them to move out of the typical immigrant neighborhoods. Their children go to middle-class schools in the well-to-do neighborhoods of Rotterdam. However, their success story is contrasted by a considerable group within the second generation that lags behind. They left school without a diploma, often marry young and, also more often, marry a partner from the country of migration of their parents. As a result, in these households there is often a parent from the first generation. Also, there is at most one income from a low-wage job, though often these households depend entirely on benefits. These children grow up in majority-minority neighborhoods, where the people of Dutch descent form a tiny minority. These children often go to the worst-performing schools. This increased socio-economic diversity within ethnic groups is an important new reality of the superdiverse city of Rotterdam.

The children of immigrants, the second and the third generations, are inheriting the city of Rotterdam. They make up about two thirds of the Rotterdam population of the future. As a result, what is the future of Rotterdam? We have shown that the most prominent trend within the second generation is polarization. The group that was able to move up into the lower and upper middle-class is equally large - or for some ethnic groups even larger - as the group in the working class. The question is whether it will be the lower-class group determining the direction the city is moving to, or the more successful group. The high educated second generations seem to lead the emancipation of women. They are the first to break away from traditional gender roles and to gain financial independence. They are also the first to claim autonomy and take progressive stands in issues of sexuality. These women set an example for their younger peers and for their children, the third generation. We find evidence pointing to this scenario among most of the high educated second generation Turks and Moroccans in Rotterdam. However, we also see a tendency among a subgroup of high educated second generation Moroccans who primarily interact with co-ethnics and who support orthodox religious ideas. The often-held idea that upward socio-economic mobility results in a smooth integration does not seem to materialize for the whole group. An important contextual factor which might explain this difference is that these high educated young people needs to fight themselves into professional positions still primarily held by a 'white' elite of Dutch descent. The more negative profiling of Islam in Rotterdam, especially, the more negative profiling of people of Moroccan descent may have triggered a reactive identity among this highly educated group (See also Crul and Lelie in Chap. 10 of this volume).

What about the low educated and low-income group? What kind of scenario will they trigger for the future of Rotterdam? A subgroup of Turkish-Dutch early school leavers seems to become marginalized. They withdraw into their own ethnic group. In general, these Rotterdam inhabitants hold very conservative ideas on gender and sexuality and show a lot of support for orthodox religious views. Children growing up in these families do so in households living close to or under the poverty line and their outlook on society could turn out to be very negative. 
Among the Moroccan-Dutch early school leavers we see an opposite effect. They do not withdraw into their own ethnic group but mix with people from different ethnic origins in a similar socio-economic position. As a result, this sub group of Moroccan-Dutch early school leavers seems to move away from traditional conservative norms and values in their ethnic community.

This overview shows that the picture of the second generation in Rotterdam is complex. An intersectional approach in which generation, socio-economic position and ethnicity all play a role seems to be much more appropriate than an approach looking at ethnic groups alone. It is exactly the increased diversity within ethnic groups that underscores the concept of superdiversity for cities like Rotterdam. The combination of being not just highly educated, but also being of Moroccan descent, and second generation, female and wearing a head scarf is more than only being a highly educated woman or only being of Moroccan descent or only being a Muslim. All these characteristics together form a radically different reality than the single characteristics do alone. That far more complex picture is needed to fully understand the dynamics in superdiverse cities like Rotterdam.

\section{References}

Arnaut, K. (2012). Super-diversity: Elements of an emerging perspective. Diversities, 14(2), 1-16. Crul, M. (2001) 'De sleutel tot succes: over hulp, keuzes en kansen in de schoolloopbanen van Turkse en Marokkaanse jongeren van de tweede generatie'. Amsterdam: Het Spinhuis

Crul, M. (2015). Super-diversity vs assimilation. How complex diversity in majority-minority cities challenges the assumptions of assimilation. Journal Ethnic and Racial Studies, 42, 42-68.

Crul, M., Schneider, J., \& Lelie, F. (2012). The European second generation compared. Does the integration context matter? Amsterdam: Amsterdam University Press.

Crul, M., Schneider, J., \& Lelie, F. (2013). Super-diversity. A new perspective on integration. Amsterdam: Free University Press.

de Boom, J., van San, M., \& Weltevrede, A. (2010). Antilliaanse en Marokkaanse Rotterdamers 2010. Een monitor van hun maatschappelijke positie. Rotterdam: Gemeente Rotterdam en RISBO.

de Boom, J., Weltevrede, A., van Wensveen, P., Seidler, Y., van San, M., \& Hermus, P. (2014). Rotterdamse Risicogroepen 2014. Een monitor van de maatschappelijke positie van Rotterdamse risicogroepen. Rotterdam: Risbo/Erasmus Universiteit.

Engbersen, G. (2014). Van zijstroom tot hoofdstroom van beleid. Rotterdam: Erasmus Universiteit en Gemeente Rotterdam.

Entzinger, H., \& Scheffer, P. (2012). De staat van integratie. Rotterdam: Gemeente Rotterdam en Amsterdam.

Gemeente Rotterdam. (2012). Bevolkingsprognose Rotterdam 2013-2030. Rotterdam: Gemeente Rotterdam.

Gemeente Rotterdam. (2018). De staat van de stad. Rotterdam: Gemeente Rotterdam.

Kasinitz, P., Waters, M., Mollenkopf, J., \& Holdaway, J. (2008). Inheriting the city. Children of immigrants come of age. New York: Russell Sage Foundation Publications.

Keskiner, E. (2015). Is it merit or cultural capital? The role of parents during early tracking in Amsterdam and Strasbourg among descendants of immigrants from Turkey. Comparative Migration Studies, 3(1), 1. 
Oudhof, K., Harmsen, C., Loozen, S., \& Choenni, C. (2011). Opvang en spreiding van Surinaamse groepen in Nederland. Den Haag: CBS bevolkingstrends 2e kwartaal.

Portes, A., \& Rumbaut, R. (2001). Legacies: The story of the immigrant second generation. Los Angeles: University of California Press.

Scheffer, P., \& Entzinger, H. (2012). De staat van integratie: Amsterdam en Rotterdam vergeleken. Amsterdam: Gemeente Amsterdam en Rotterdam.

van Niekerk, M. (2007). Second-generation Caribbean's in the Netherlands: Different migration histories, diverging trajectories. Journal of Ethnic and Racial Studies, 33(7), 1063-1083.

Open Access This chapter is licensed under the terms of the Creative Commons Attribution 4.0 International License (http://creativecommons.org/licenses/by/4.0/), which permits use, sharing, adaptation, distribution and reproduction in any medium or format, as long as you give appropriate credit to the original author(s) and the source, provide a link to the Creative Commons license and indicate if changes were made.

The images or other third party material in this chapter are included in the chapter's Creative Commons license, unless indicated otherwise in a credit line to the material. If material is not included in the chapter's Creative Commons license and your intended use is not permitted by statutory regulation or exceeds the permitted use, you will need to obtain permission directly from the copyright holder. 